This is a pre-proof version of an article in Canadian Journal of Earth Sciences

Weaver, K. and Arnaud, E. in press. Distribution of strain signatures in Quaternary sediments, Regional Municipality of Waterloo, Ontario, Canada. Canadian Journal of Earth Sciences.

The definitive version is available at http://pubs.nrc-cnrc.gc.ca/rpps/journalDetail.jsp?.jcode $=$ cjes 
This paper is in press in the Canadian Journal of Earth Sciences

\section{Distribution of Strain Signatures in Quaternary Sediments, Regional Municipality of Waterloo, Ontario, Canada}

Laura Weaver, Emmanuelle Arnaud ${ }^{1}$, Andy Bajc

Laura Weaver: AquaResource Inc., 31 Beacon Point Court, Breslau, ON, Canada, N0B 1M0 Emmanuelle Arnaud: School of Environmental Sciences, University of Guelph, Guelph, ON, Canada, N1G 2W1 Andy Bajc: Ontario Geological Survey, 933 Ramsey Lake Road, Sudbury, ON, Canada, P3E 6B5

${ }^{1}$ Corresponding author. earnaud@uoguelph.ca 
Distribution of Strain Signatures in Quaternary Sediments, Regional Municipality of Waterloo, Ontario, Canada

Laura Weaver, Emmanuelle Arnaud, and Andy Bajc

\section{Abstract}

A geodatabase of deformation structures with over 300 field observations and 53 attribute fields was compiled to assess the significance of soft-sediment deformation in Quaternary sediments in the Regional Municipality of Waterloo as they relate to existing depositional models and regional ice sheet dynamics. The regional distribution of morphologically diverse deformation structures is interpreted to reflect localized ice margin fluctuation as well as extensive gravity driven deformation associated with rapid sedimentation, sediment remobilization, or melting of buried or supporting ice in a glaciolacustrine setting. Deformation was often observed in coarse-grained sediment and included attenuated and chaotic bedding, shear folds, dikes, and reverse and normal faulting. It ranged in scale and complexity from an isolated centimetre scale occurrence to entire metrescale outcrops exhibiting multiple types of deformation at various scales. Some of the deformation was observed in clusters of several square kilometres, with deformation within the cluster being predominantly large scale and complex in coarse-grained sediments. These deformation structures can be attributed to simple shear and/or compressional stress or stresses related to gravitational instability. Simple shear and compressional deformation are most common in localized areas of the moraine and in the surrounding till plains. In contrast, deformation related to gravitational instability is widespread and most common in the eastern half of the region. The coarse-grained texture and complex nature of deformation within 
clusters has implications for subsurface heterogeneity, and consequently, local groundwater flow regimes and contaminant transport at the well field scale. 


\section{Introduction}

The Waterloo Moraine is a complex ice-marginal feature consisting primarily of stratified sand and gravel and intervening, discontinuous lenses of diamicton and pebbly mud (Karrow and Paloschi 1996), which was deposited between several lobes of the Laurentide Ice Sheet during the Wisconsin glaciation (Fig. 1; Barnett 1992). Spatially restricted depositional settings have been interpreted from Quaternary sediment at various sites within the Waterloo Moraine, creating a mosaic of paleoenvironments (Bajc and Karrow 2004), which include quiet water basinal, deltaic, subaquatic fan, glaciofluvial, and subglacial (Bajc and Shirota 2007; Russell et al. 2007). While a regional hydrogeologic framework exists, the precise spatial distribution and extent of these depositional settings and the subsurface architecture of the moraine are poorly constrained. In addition, the history of development of the moraine over time and its record of ice dynamics in the region remain uncertain.

Reconstructions of the depositional history of the Waterloo Moraine are based on regional till stratigraphy, as well as the nature, distribution, and relative stratigraphic position of its stratified sediments (Karrow et al. 1986; Karrow 1988; Barnett 1992; Paloschi 1993; Rajakaruna 1994; Bajc and Shirota 2007); deformation structures have received little attention to date (Weaver and Arnaud In press; Gao 2005). Yet, when coupled with facies analysis, deformation structures have been shown to provide critical information to determine environmental conditions and the nature of ice dynamics, such as active vs. stagnant ice, and ice advances into terrestrial vs. lacustrine or marine settings, at particular sites (Hart and Roberts 1994; Benn and Evans 1996; Boulton et al. 1999; Phillips et al. 2002; McCarroll and Rijsdijk 2003; Arnaud 2008). 
This paper aims to refine the depositional models of the Waterloo Moraine and better delineate active ice in the region through the analysis of the distribution of deformation structures in the region using a geodatabase (311 field sites with 53 attribute fields) ${ }^{2}$. Technical aspects of geodatabase creation and metadata information are discussed in more detail in supplementary material available with this article. The use of a geodatabase in this context is novel as it presents a unique opportunity to look at stresses at a regional scale, most suitable for reconstructing depositional settings and glacier dynamics. Analysis focused on the detailed morphological and sedimentological description of deformation structures at numerous outcrops to establish the spatial variability of deformation. Identifying triggers for the observed deformation based on this analysis is then used to refine existing regional depositional models for the moraine and better delineate the distribution of active ice in the region. The spatial database was also employed to identify local areas of enhanced subsurface hydrogeologic complexity related to macroscopic deformation.

\section{Geological Background}

Deformation structures commonly observed in the Regional Municipality of Waterloo (RMOW) can be classified into three broad types based on morphological and structural characteristics: strain associated with compressional, simple shear, and gravitational stresses. Compressional strain records the horizontal shortening of a sedimentary unit in response to an encroaching mass (McCarroll and Rijsdijk 2003), and includes open to closed folds, overturned folds, nappes, compressional fractures, and dikes (e.g. Boulton et al. 1999). Simple shear strain records the effects of tangential and/or horizontal stress on or within a

\footnotetext{
${ }^{2}$ Table S1
} 
sedimentary body involving the displacement and elongation of sedimentary structures in the direction of maximum shear (McCarroll and Rijsdijk 2003). Simple shearing is common in subglacial and ice-marginal environments where ice and/or sedimentary bodies over-ride underlying sediment (Hart and Roberts, 1994; McCarroll and Rijsdijk 2003). Rooted and detached shear folds, attenuated beds and thrust faulting are commonly observed simple shear structures. Gravitational deformation results from the vertical displacement of sediment in response to gravity-driven processes, which include the collapse of the sedimentary floor from melting of buried ice blocks (McDonald and Shilts 1975), remobilized sediment (Nardin et al. 1979) and reversed density gradients in saturated sediment (Anketell et al. 1970). Examples of gravitational deformation include normal and high angle reverse faulting, ball and pillow structures, and chaotic bedding. The relative abundance and association of macroscopic deformation styles can be used to delineate areas affected by distinct large-scale stresses, which in turn can help determine the spatial extent of active glacial ice and depositional environments present during the formation of the Waterloo Moraine.

The Waterloo Moraine rises up to $\sim 100 \mathrm{~m}$ from the surrounding plains as a very irregular mass with an undulating topography (Karrow and Paloschi 1996; Bajc and Shirota, 2007). Examination of ground surface topography using a $10 \mathrm{~m}$ resolution digital elevation model (Ministry of Natural Resources 2002) reveals a regional SE-NW trending ridge that forms the central core of the moraine (Fig. 2). The ridge is $\sim 60 \mathrm{~m}$ higher than the surrounding moraine surface.

Multiple till units have been recognized in the immediate vicinity of the moraine. They overlie, are interbedded with, and underlie the stratified granular deposits that comprise the feature (Fig. 3; Karrow and Paloschi 1996; Bajc and Karrow 2004; Bajc and Shirota 2007; 
Russell et al. 2007). Drumlinized and non-drumlinzed Huron lobe Tavistock and Mornington till, and Erie-Ontario lobe Port Stanley till plains onlap the moraine from the northwest and southeast, respectively. The Maryhill Till, persistent at surface along the western flank and central core of the moraine, occurs as discontinuous lenses above, within, and below the stratified sediments of the moraine. At depth, the regionally extensive Catfish Creek Till is the main Late Wisconsin (Nissouri Phase) till sheet on which the moraine is built. Spillway deposits associated with the Grand River can be found to the southeast of the moraine.

Tills identified in the region record local and regional ice advances before (Canning Drift, Catfish Creek Till), during (Maryhill Till) and following (Tavistock, Mornington, and Port Stanley tills) the development of the moraine (Fig. 3). However, event chronology is largely unconstrained by radiometric dates, making correlation of till units within the moraine difficult and overall constraints on stratigraphy and moraine development tenuous.

Stratigraphic relationships suggest that the moraine formed during the late Nissouri to early Port Bruce Phase (Karrow and Paloschi 1996; Bajc and Karrow 2004; Bajc and Shirota 2007). The stratified sediment of the Waterloo Moraine is thought to have been deposited by a westward prograding delta-fan system into an ice-supported water body between the ErieOntario and Huron-Georgian Bay lobes (Bajc and Shirota 2007). The regional NW-SE trending ridge has been interpreted as a number of coalesced, ice-contact subaqueous fans deposited along the retreating Erie-Ontario ice margin; this ridge would have formed as the ice margin progressively retreated towards the southeast (Bajc and Shirota 2007). Further retreat of the Erie-Ontario and Huron-Georgian Bay lobes following the deposition of the Waterloo Moraine likely resulted in rapid drainage of the glacial lake, leading to dissection of the moraine (Bajc and Shirota 2007). 
If the regional ridge is actually the remains of ice-contact fans, the geodatabase of sites with deformed sediments should reveal a difference in the nature, distribution, and associations of deformation structures along, and on opposing sides of, the ridge.

\section{Methodology}

There were three components to this study: (i) field data acquisition, (ii) geodatabase construction, and (iii) data analysis. Field observations were made at aggregate quarry exposures, road and river cuts, and excavations of new houses throughout the RMOW (Fig. 2), as part of a research program at the University of Guelph and a regional three-dimensional aquifer mapping program by the Ontario Geological Survey.

Field data was compiled into a geodatabase that captures geographic and sedimentological information for 311 sites in 53 attribute fields including the geographic coordinates, type, dominance, scale, and sedimentological characteristics of deformation structures $^{3}$. The dominance of deformation was determined by identifying the largest deformation structure within an outcrop, or the most abundant type of deformation if numerous types of deformation had similar scales. Deformed sediment and associated undeformed sediment were described using a facies classification scheme modified from Miall (1977) and Eyles et al. (1983). Specific aspects noted include dominant and subordinate texture, scale of bedding and geometry, nature of bounding surfaces and clast characteristics (lithology, size, shape, and fabric). Due to the unstable nature of outcrops in aggregate mines and recent regulations related to scaling steep pit faces, structural data related to the geometry of fold axes and fault planes were not collected; only the offsets were measured for each type

\footnotetext{
${ }^{3}$ Tables S1, S2, S3
} 
of faulting. The acquired data have inherent spatial bias arising from the limitations of available exposures in parts of the RMOW that are heavily urbanized. Despite this, a relatively comprehensive distribution of sites was achieved (Fig. 2).

Analysis of the spatial distribution of the types and scale of deformation as well as the relationship between texture (coarse-grained, which includes sand and gravel vs. fine-grained, which includes clay, silt, and diamict) and types of deformation structures was carried out using Geographic Information Systems (GIS) and data management software. Deformation maps were then created based on query outputs of the geodatabase. The boundary of the Waterloo Moraine illustrated on these maps was taken from Bajc and Shirota (2007), and only provides a generalized outline of the Waterloo Moraine for reference to the location of deformed sites.

\section{The Nature and Regional Distribution of Deformation}

Deformation captured in the geodatabase is morphologically diverse and complex. Outcrop-scale deformation was observed at 84 sites, or approximately $25 \%$ of the 311 sites surveyed (Table 1; Fig. 2). Observed deformation included both normal and reverse faulting as well as dikes, ball and pillow structures, attenuated bedding and a variety of folding. Trends in dominant deformation styles and their associated subordinate deformation styles are the focus of discussion herein. Undifferentiated faulting was observed at 6 sites $(8 \%$ of deformed sites) and is omitted from the descriptions below.

\section{Deformed sediments}


Chaotic bedding is considered mildly to highly folded (symmetric, asymmetric, anticlinal, synclinal, open to closed) sediment, with no preferred apparent fold orientation, and includes deformation structures described as chaotic bedding, contorted bedding, distorted bedding, as well as slumped bedding and flow nose. Chaotic bedding, observed at $31 \%$ of deformed sites (24/78; Table 1), ranged in scale from centimetres to metres and affected all types of sediments (Fig. 4). The bases of chaotic beds were generally sharp with the underlying material, and at times inclined (Fig. 4A). Eight of the sites characterized by chaotic bedding were associated with shear structures in adjacent beds or along the basal contact of chaotic beds. Dominant chaotic bedding was otherwise associated with faulting, attenuated bedding, dikes, and ball and pillow structures.

Attenuated beds are stretched or boudinaged beds (also referred to as tectonic laminations; Hart and Roberts 1994). Attenuated beds were observed at $13 \%$ of the deformed sites (10/78 sites) and tended to be found in metre scale units of interbedded sand and mud (Table 1; Fig. 5A). One site was characterized by an attenuated sand unit of the same scale in predominantly gravelly sediment. Attenuated beds are most commonly associated with chaotic bedding, shear folds, and occasionally with reverse faulting.

Ball and pillow structures, flame structures, and convolute bedding were observed at $5 \%$ of deformed sites (4/78 sites) as the dominant deformation type (Table 1). Two sites exhibited small-scale loading structures $(\sim 8 \times 15 \mathrm{~cm})$, whereas a large metre-scale loading structure consisting of a load cast (1.1 x $1.5 \mathrm{~m})$, a flame structure $(75 \times 65 \mathrm{~cm})$, and a pseudonodule (10 x $18 \mathrm{~cm})$, was observed at another site (Fig. 5B). The large-scale loading structure was observed within the main body of the moraine. In all cases, loading structures were observed where relatively coarser-grained sediment overlies finer-grained sediment. 
Two of the four sites had no subordinate deformation, whereas one had chaotic bedding and bed-scale reverse faulting associated with the ball and pillow structures and the other was associated with open folding in sand.

Normal faulting was observed at 29\% (23/78 sites) of the deformed sites surveyed in the RMOW (Table 1). Faults are found in all types of sediments, although they predominantly cross-cut cut-fill sequences of very fine- to very coarse-grained sand and pebble to cobble gravel (Figs. 6,7A). Isolated sites of normal faulting were also observed within interbedded sand, gravel and mud. Normal faulting has offsets that range from $0.5 \mathrm{~cm}$ to $175 \mathrm{~cm}$, and can be commonly traced through entire outcrop exposures. Several sites show clear graben structures ranging in vertical thickness from tens of centimetres to metre-scale. Normal faults are observed in otherwise undeformed sediment (14 of 23 sites) or in association with ball and pillow structures, chaotic bedding, and reverse faulting (nine of 23 sites).

Reverse faults with offsets of $0.5 \mathrm{~cm}$ to $2 \mathrm{~m}$ were observed at $14 \%$ of deformed sites (11/78 sites; Table 1; Figs. 7B, 8). Low-angle thrust faulting was observed at two of the 11 sites. Reverse faults primarily affect sand units as well as interbedded sand and mud or interbedded sand and gravel. Reverse faults either extend vertically through the entire outcrop, or are localized and affect only several stratigraphic units within an outcrop face. Many sites with dominant reverse faulting did not have any observed associated subordinate deformation features; however, five of 11 sites were observed in conjunction with normal faulting, chaotic bedding, or ball and pillow structures.

Rooted shear folds in mud and very fine-grained sand to pebble gravel were recorded as the dominant type of deformation at $4 \%$ of the deformed sites surveyed (3/78 sites; Table 1 ; Fig. 5C). Shear folds are elongated lenses of sediment, which have formed in response to a 
shearing mechanism and remain attached to the parent sedimentary body. Observed shear folds are tens of centimeters to one metre in size. Shear folds are commonly associated with attenuated and chaotic bedding.

Dikes are vertical masses of unconsolidated sediment that have been injected into extensional fractures in a host body of contrasting lithology. Dikes were observed at $4 \%$ of the deformed sites ( $3 / 78$ sites) intruding downwards in a random fashion from an overlying diamict unit into sand (Table 1; Fig. 5D). They generally extend several tens of centimeters, up to $2.5 \mathrm{~m}$, in length, and are $\sim 1$ to $20 \mathrm{~cm}$ wide. Dike walls are primarily sharp, but irregular. Diamict, silty clay and/or very fine to medium-grained sand dikes with deformed internal laminations primarily parallel to the dike wall were observed to extend into sand bodies. Dikes are associated with shear folds and attenuated bedding.

Overall, the complexity and vertical scale of the deformation ranges widely from single occurrence of small $(<5 \mathrm{~cm})$ to very large $(>2 \mathrm{~m})$ deformation structures (Figs. $4,5,7,8)$, to entire outcrops that are characterized by multiple deformation structures at various scales (Figs. 6, 9). Approximately $41 \%$ of deformed sites are characterized by complex deformation where three types of deformation (dominant, subordinate and sub-subordinate) are reported at a given outcrop.

\section{Origin of deformation}

Observed attenuated beds, shear folds, dikes, and low-angle reverse faulting are interpreted as simple shear and compressional strain signatures (Table 1). Simple shear stress associated with subglacial conditions are recorded as bed attenuation and shear folds in modern or ancient glacial sediments (Hart and Roberts 1994; Benn and Evans 1996; 
McCarroll and Rijsdijk 2003), and the ones observed here are interpreted to record glacial over-riding. At two of the three sites surveyed, dikes were observed to extend into a sand bed from an overlying diamict unit. The diamict unit had shear folds and attenuated bedding along its base. These dikes are interpreted as having formed when tangential and compressional stresses associated with basal simple shear and subglacial deposition of the overlying diamict led to extensional fractures and downward injection of diamict into the sand (Le Heron and Etienne 2005). The low-angle reverse faulting likely resulted from simple shear and/or compressional stresses associated with ice advance (Benediktsson et al. 2008; Bennett et al. 2004), though it is difficult to isolate which of these stresses was most significant in their formation (Table 1).

Simple shear stress dominates in subglacial environments, whereas compressional stress is most prevalent in ice-marginal environments (Hart et al. 1990; Boulton et al. 1999; McCarroll and Rijsdijk 2003; Benediktsson et al. 2008); however simple shear and compressional strain are also observed in association with sediment gravity flow deposits (Nardin et al. 1979). Simple shear and compressional deformation structures related to sediment remobilization can be distinguished from those associated with active ice: deformation associated with sediment gravity flow deposits are generally found at the base of a single sedimentary unit or in front of a flow nose, and tend to be associated with structures related to water escape or loading (Hart and Roberts 1994). In contrast, deformation structures associated with active ice tend to affect the whole sedimentary package (Hart and Roberts 1994). The complexity and scale of the observed simple shear and compressional deformation structures (Fig. 5A) suggest these formed as a result of stresses imparted by active ice. 
The other deformation structures (chaotic bedding, ball and pillow and flame structures, and normal/high angle reverse faulting) can be attributed to gravitational instability (Table 1) Chaotic bedding deformation structures had characteristics typical of sediment gravity flows, such as a basal shear zone, flow nose, and in some cases a steep depositional slope (Fig. 4A). These deformation structures are interpreted as the product of slumping, sediment remobilization, and deposition of sediment gravity flows (Nardin et al. 1979). Ball and pillow structures and flame structures, also referred to as loading structures, can be attributed to rapid sedimentation and the development of reversed density gradients in saturated heterogeneous sediment (Anketell et al. 1979; Mills 1983). Convolute bedding is also typically attributed to gravity induced deformation through reversed density gradients and Rayleigh Taylor instability (Dott and Howard 1962; Davies 1965; Allen 1977; Visher and Cunningham 1981). The association of coarser-grained sediment overlying finer-grained sediment likely induced sediment liquefaction and deformation. The rapid loading of sediments with different densities is typical of subaquatic fan settings. Lastly, observed normal and high angle reverse faulting is attributed to the melting of buried ice and the collapse of unsupported sediment (McDonald and Shilts 1975; Aitken 1998) or the end of icecontact conditions and the removal of ice support.

In summary, the deformation structures identified in the RMOW can be attributed to simple shear and compressional stresses associated with active ice, as well as gravitational instability stresses associated with localized downslope sediment remobilization, reversed density gradients and rapid sedimentation, and the melting of buried or supporting ice (Table $1)$. 


\section{Undeformed Sediment}

Undeformed sediment was observed at $73 \%$ of all the sites surveyed (227/311)

throughout the RMOW (Fig. 2). Thick successions of undeformed tabular and cut-fill gravel, channelized sand units, and tabular successions of interbedded mud, sand and gravel beds are found within the moraine, and surrounded by till sheets and glaciofluvial outwash on the peripheries. Clasts are of mixed lithology, subangular to rounded, and low sphericity. Generally, very fine- to very coarse-grained sand is the most readily recorded sediment texture in the Waterloo Moraine. Sand is observed to fine laterally westward beyond the regional ridge, whereas east of the ridge, vertically and laterally heterogeneous undeformed interbedded mud, sand and gravel predominate.

\section{Spatial Trends in Deformation}

Deformation throughout the RMOW is complex, and spatially variable; however, some spatial trends do emerge. Regionally, deformation appears to be predominantly found on and east of the regional SE-NW trending ridge (Figs. 2, 10). More specifically, deformation associated with gravitational instability was the most prevalent deformation style (51 out of 78 deformed sites or $65 \%$, Table 1), particularly in the heterogeneous sediment of the main moraine body and on the east side of the moraine (Fig. 10). In contrast, dominant simple shear and compressional strain signatures (27 out of 78 deformed sites or $35 \%$, Table 1 ) were predominantly observed along the regional SE-NW trending ridge. Undeformed sediments were observed throughout the RMOW (Fig. 10).

Deformation was observed predominantly in coarse-grained sediment (Fig. 11): 69\% of deformed sites (58/84 sites) had dominant deformation in coarse-grained sediment (sand 
and gravel) compared to $31 \%$ of deformed sites (26/84 sites) with dominant deformation in fine-grained sediment (clay, silt, and diamict). There was no relationship between type of deformation and texture. Only $21 \%$ of surveyed deformed sites (16/78 sites) had observed deformation involving (five), or in association with (11), diamict, all of which were located near areas that have been mapped as Mornington, Maryhill, Port Stanley, Wentworth or Tavistock tills at surface (Fig. 12; Ontario Geological Survey 2010).

Most observed deformation structures had a vertical thickness of $<0.25$ or $>2 \mathrm{~m}$ (Fig. 13, Table 2). Widespread small-scale deformation $(<0.25 \mathrm{~m}$ thick) occurs in interbedded heterogeneous sediments, whereas large-scale ( $>2 \mathrm{~m}$ thick) deformation occurs predominantly in sand and gravel. Deformation structures $<0.25 \mathrm{~m}$ thick are most commonly chaotic bedding related to gravitational instability, with others including attenuated bedding, shear folds, reverse faults, and ball and pillow structures. In contrast, deformation structures $>2 \mathrm{~m}$ thick are most commonly related to faulting, with others including chaotic or attenuated bedding, and dikes.

While many of the deformation sites occur as spatially isolated points throughout the moraine, deformation also occurred in two clusters or deformed complexes covering several square kilometres (Fig. 10). Although the nature of urban development in the region has imprinted a certain bias to the distribution of the data points, additional data would likely reinforce the established zonation of deformed sediments, whereby complexes would be surrounded by observations of undeformed sediment and maintain their current areal extent, or increase in size if more deformed sediment is observed in close proximity.

Deformation structures driven by gravitational instabilities commonly occurred as isolated observations; however, gravity-induced deformation was also observed along the 
regional ridge within, and in close proximity to, the complexes. In contrast, sites with dominant simple shear and compressional strain were observed in close proximity (within 100 m) to each other, forming these deformed complexes (Fig. 10). Generally, most sites in the deformation complexes were characterized by complex, large-scale deformation of coarsegrained sediment (Figs. 11, 13).

\section{Discussion}

\section{Regional trends, triggers, and depositional context of deformation}

Deformation related to gravitational instability was the dominant type of deformation observed. It was most common to the northeast of the regional ridge (Figs. 10, 14). By contrast, simple shear and compressional deformation features were observed along the trend of the regional ridge as well as on the Hawkesville Spur on the north side of the moraine, and in the surrounding till plains (Figs. 10, 14). However, they were much less common.

Gravity-induced deformation structures are most common in glaciolacustrine, glacially-influenced fan delta systems and proglacial environments (Hart and Roberts 1994;

Hunter et al. 1996; McCarroll and Rijsdijk 2003), where the deformation is related to sediment remobilization, rapid sedimentation of heterogeneous sediments as well as melting of buried ice (Lønne 1995). The distribution of the deformation northeast of the ridge suggests that late stages in moraine formation were dominated by glaciolacustrine or proglacial conditions as the ice retreated from the region (Fig. 14).

Calcite content of sand taken from the Waterloo Moraine indicates an eastern sediment source (Chapman and Dell 1963), which was further supported by dominant west-northwest paleoflow directions documented by Bajc and Shirota (2007). It is therefore suggested that the 
simple shear and compressional deformation structures observed in association with the ridge were formed as a result of minor fluctuations in the Ontario-Erie ice margin during the late stages of moraine development and overall ice retreat from the region (Fig. 14).

Simple shear and compressional deformation was also observed in the Hawkesville Spur (Figs. 2, 12). The Hawkesville Spur has been interpreted as an ice-walled conduit feeding the main body of the moraine, with the majority of sediment deposited under glaciofluvial conditions (Bajc and Shirota 2007; Russell et al. 2007). The presence of a diamict overlying the glaciofluvial deposits suggests it may have been a subglacial conduit (Russell et al. 2007). Simple shear and compressional deformation observed in the Hawkesville Spur suggests that active ice was another important process in this area.

The surrounding till plains have sites with deformation related to gravitational instability and, to a lesser extent, simple shear and compressional strain. This suggests that many areas were affected by proglacial or subaqueous deformation such as sediment remobilization and/or melting of buried ice, whereas some others can be characterized as affected by active ice deformation (Fig. 14).

\section{Texture and hydrogeologic characteristics of deformation structures}

Few studies focus on deformation in stratified sand and gravel (Hart and Watt 1997; Rijsdijk et al. 2010); rather, most document deformation involving diamict (Boulton 1972; van der Meer et al. 2003; Roberts and Hart 2005; Larson et al. 2006; Piotrowski et al. 2006); and of these, many are found in ice marginal settings where glaciotectonic deformation results from surging ice, ice push, and bulldozing of poorly sorted debris during ice advance.

Interestingly, $69 \%$ of deformed sites were observed in coarse-grained sand and gravel in this 
study (Fig. 11). Only 21\% of surveyed deformed sites (16/78 sites) were observed within or in association with diamict and these were often associated with the regional ridge or the surrounding till plains (Fig. 12). These findings suggest that deformation in interlobate settings is distinctly different. It is primarily related to slumping and rapid sedimentation of coarse-grained sediments under glaciolacustrine conditions, as well as ice overriding relatively well-sorted glacial outwash and subaquatic fan deposits.

This regional spatial analysis of deformed sediment was also used to highlight areas of increased subsurface heterogeneity as delineated by complexes of $>1 \mathrm{~m}$ thick deformation structures. The spatial extent of these deformed complexes have some broader implications in the context of hydrogeologic characterizations of Quaternary overburden, which are used to assess municipal groundwater supply in many parts of Ontario. Stratified moraines (e.g., Waterloo Moraine, Oak Ridges Moraine, Orangeville Moraine, and Oro Moraine) have been identified as multi-aquifer complexes, which are often exploited to supply groundwater resources to neighbouring urban centres (Howard et al. 1997; Barnett et al. 1998; Krzyszkowski and Karrow 2001; Burt 2006; Bajc and Shirota 2007; Burt 2008). As stratified moraines are a product of a dynamic environment characterized by periods of deposition in glaciolacustrine or fan-delta settings and periods of erosion and reworking as a result of active ice or rapid drainage of ice-walled lakes, their subsurface architecture is often complex.

Regional spatial analyses of deformed sediment can highlight areas of increased subsurface heterogeneity in coarse-grained, aquifer sediment by delineating complexes of vertically and laterally extensive deformation (Huggenberger and Aigner 1999). This becomes important as increased vertical sediment heterogeneity may influence inferred groundwater flow and contaminant migration pathways in coarse-grained aquifer units 
traditionally considered relatively homogenous (Busby and Merritt 1999; Martin and Frind 1998), thereby rendering groundwater flow models locally erroneous at the well field scale (Huggenberger and Aigner 1999). Delineating the areal extent of deformed complexes, similar to those found in this study, may provide additional insight when constructing subsurface hydrogeologic conceptualizations. In addition, identifying the nature and origin of these deformed complexes may allow for better estimates of horizontal and vertical hydraulic conductivity values used to characterize these heterogeneous sediments in numerical groundwater flow models.

Analysis in this study focused on deformation structures observed in coarse-grained sediment in the near-surface, unsaturated zone of the surficial aquifer of the Waterloo Moraine. Deformed sediments have also been documented at depth in cores drilled in the Waterloo Moraine (Bajc and Hunter 2006). Considering the dynamic conditions of an interlobate setting and the evidence for ice margin fluctuations (Maryhill Till) within the moraine (Fig. 3), deformed complexes similar to the ones documented here are expected to occur at depth. The resulting subsurface heterogeneity may in part explain some of the difficulty encountered when developing detailed hydrogeologic conceptualizations used in groundwater modeling.

\section{Conclusion}

A regional study was conducted on surficial sediment within the RMOW to characterize the spatial variability of macroscopic deformation structures in a setting that was influenced by multiple ice lobes. A geodatabase was compiled from field observations at 311 sites, and used to examine spatial trends in texture, morphology, and scale of strain signatures 
at the regional scale. Throughout the region, deformation structures are structurally variable, and include faulting, load structures, chaotic bedding, attenuated bedding, dikes, and a wide variety of folds. These deformation structures can be attributed to stresses related to gravitational instability or simple shear and compressional stress.

The regional distribution of deformation styles can be described as follows: deformation related to gravitational instability is the most commonly observed deformation styles, and is most commonly recorded to the northeast of a centrally located, ice-marginally deposited ridge; whereas, simple shear and compressional deformation were found along the trend of the regional ridge, on a localized spur or arm of the moraine and in the surrounding till plains. These findings support current depositional models of the moraine where (i) glaciolacustrine conditions, with abundant gravity driven processes, dominate; (ii) the regional ridge is thought to record the position of coalesced subaquatic fans deposited in an ice-contact environment during the overall retreat of the ice margin from the region; and (iii) the Hawkesville Spur is interpreted as a subglacial conduit feeding sediment from the north into the moraine.

In addition to the spatial trends associated with the deformation, deformation occurred in all sediment types with up to $69 \%$ of the deformation occurring in sand and gravel. Structures were most commonly $<0.25$ or $>2 \mathrm{~m}$ in size. A clustered spatial distribution of deformation structures permits the delineation of $\mathrm{km}^{2}$-scale deformed complexes. These deformed complexes may alter inferred groundwater flow and/or contaminant migration pathways in these areas in response to increased lateral and vertical sediment heterogeneity traditionally not captured in hydrogeologic conceptualizations. 


\section{Acknowledgements}

The authors would like to thank the many operators that let us into their aggregate quarries, Peter Martini for helpful discussions throughout the project, and Sarah Ouellette for her assistance in the field. This research was funded by a Natural Sciences and Engineering Research Council Discovery Grant to Arnaud and a University of Guelph Scholarship and Ontario Graduate Scholarship to Weaver. We also acknowledge the Ontario Geological Survey for funding portions of the fieldwork under its Groundwater Mapping Program. This financial assistance is greatly appreciated. Detailed comments and suggestions by reviewers (Don Cummings and Kenneth Rijsdijk) and the Associate Editor (Timothy Fisher) have greatly improved the manuscript and are much appreciated. 


\section{References}

Aitken, J.F. 1998. Sedimentology of Late Devensian glaciofluvial outwash in the Don Valley, Grampian Region. Scottish Journal of Geology, 34: 97-117.

Allen, J. R. L. 1977. The possible mechanics of convolute laminations in graded sand beds. Journal of Geological Society, London, 134: 19-31.

Anketell, J.M., Cegla, J., and Dzulynski, S. 1970. On the deformational structures in systems with reversed density gradients. Rocznik Polskiego Towarzystwa Geologicznego, 40: $3-30$.

Arnaud, E. 2008. Deformation in the Neoproterozoic Smalfjord Formation, northern Norway: an indicator of glacial depositional conditions? Sedimentology, 55(2): 335-356.

Bajc, A. F. 2004. Three-dimensional mapping of Quaternary deposits in Waterloo Region, southwestern Ontario, in Summary of Field work and other activities. Ontario Geological Survey Open File Report, 6145, pp 24-1 to 24-4.

Bajc, A. F. and Karrow, P. F. 2004. 3-dimensional mapping of Quaternary deposits in the Regional Municipality of Waterloo, southwestern Ontario, Lake to Lake: GAC-MAC Joint Annual Meeting. Geological Association of Canada/Minerological Association of Canada, FT-7, St. Catherines, ON. 72p.

Bajc, A. F. and Hunter, J. A. 2006. Results of the 2003-2004 overburden drilling programs in the region of Waterloo, southwestern Ontario. Ontario Geological Survey, Miscellaneous release, Data 205.

Bajc, A. F. and Shirota, J. 2007. Three-dimensional mapping of surficial deposits in the Regional Municipality of Waterloo, southwestern Ontario; report in Ontario Geological Survey, Groundwater Resources Study 3, 42p. 
Barnett, P. J. 1992. Quaternary Geology of Ontario. In Geology of Ontario. Edited by P.C. Thurston, H.R. Williams, R.H. Sutcliffe and G.M. Stott, Ontario Geological Survey, Toronto, Ontario. pp. 1011-1090.

Barnett, P.J., Sharpe, D.R., Russell, H.A.J., Brennand, T.A., Gorrell, G., Kenny, F.M. and Pugin, A. 1998. On the origin of the Oak Ridges Moraine. Canadian Journal of Earth Sciences, 35: 1152-1167.

Benediktsson, Í. Ö., Möller, P. Ingólfsson, Ó, van der Meer, J. J. M., Kjær K. H., and Krüger, J. 2008. Instantaneous end moraine and sediment wedge formation during the 1890 glacier surge of Brúarjökull, Iceland. Quaternary Science Reviews, 27(3-4): 209-234.

Benn, D. I. and Evans, J. A.. 1996. The interpretation and classification of subglaciallydeformed materials. Quaternary Science Reviews, 15: 23-52.

Bennett, M. R., Huddart, D., Waller, R. I., Midgley, N. G., Gonzalez, S., and Tomio, A. 2004: Styles of ice-marginal deformation at Hagafellsjokull-Eystri, Iceland during the 1998/99 winter-spring surge. Boreas 33, 97-107.

Boulton, G. S. 1972. Modern arctic glaciers as depositional models for former ice sheets. Journal of the Geological Society of London, 128: 361-393.

Boulton, G. S., van der Meer, J. J. M. Beets, D. J., Hart, J. K., and Ruegg, G. H. J. 1999. The sedimentary and structural evolution of a recent push moraine complex: Hølmstrombreen, Spitsbergen. Quaternary Science Reviews, 18: 339-371.

Burt, A.K. 2006. Three-dimensional geological modelling of thick Quaternary deposits in the Barrie area, central Ontario; in Summary of Field Work and Other Activities 2006, Ontario Geological Survey, Open File Report 6192, p. 33-1 to 33-18. 
Burt, A. K. 2008. The Orangeville Moraine study: a new three-dimensional Quaternary mapping project; in Summary of Field Work and Other Activities 2008, Ontario Geological Survey, Open File Report 6226, p.30-1 to 30-9.

Busby, J. P., and Merritt, J. W. 1999. Quaternary deformation mapping with ground penetrating radar. Journal of Applied Geophysics, 41: 75-91.

Chapman L.J., and Dell, C. I. 1963. Revisions in the early history of the retreat of the Wisconsin glacier in Ontario based on calcite content of sands. Proceedings of the Geological Association of Canada, 15:103-108

Davies, H. G. 1965. Convolute laminations and other structures from the Lower Coal Measures of Yorkshire. Sedimentology, 5: 305-325.

Dott, R., and Howard, J. 1962. Convolute laminations in non-graded sequences. Journal of Geology, 70: 114-121.

Eyles, N., Eyles, C. H., and Miall, A. D. 1983. Lithofacies types and vertical profile models; an alternative approach to the description and environmental interpretation of glacial diamict and diamictite sequences. Sedimentology, 30(3): 393-410.

Gao, C. 2005. Ice-wedge casts in Late Wisconsinan glaciofluvial deposits, southern Ontario, Canada. Canadian Journal of Earth Sciences, 42: 2117-2126.

Hart, J. K., and Roberts, D. H. 1994. Criteria to distinguish between subglacial glaciotectonic and glaciomarine sedimentation, I. Deformation styles and sedimentology. Sedimentary Geology, 91: 191-213.

Hart, J. K., and Watts, R. 1997. Comparison of the styles of deformation associated with two recent push moraines, south Van Keulenfjorden, Svalbard. Earth Surface Processes and Landforms, 22: 1089-1107. 
Hart, J.K., Hindmarsh, R.C.A., and Boulton, G.S. 1990. Styles of subglacial glaciotectonic deformation within the context of the Anglian ice-sheet. Earth Surface Processes and Landforms, 15: 227-241.

Howard, K., Eyles, N., Smart, P. J., Boyce, J. I., Gerber, R.E., Salvatori, S. L., Doughty, M. 1997. The Oak Ridges Moraine of southern Ontario: a groundwater resource at risk. In Environmental Geology of Urban Areas. Edited by N. Eyles. Geological Association of Canada, St. John's, Nfld. pp. 590.

Huggenberger, P. and Aigner, T. 1999. Introduction to the special issue on aquifersedimentology: problems, perspectives and modern approaches. Sedimentary Geology, 129: $179-186$.

Hunter, L. E., Powell, R. D., and Smith, G. W. 1996. Facies architecture and grounding-line fan processes of morainal banks during the deglaciation of coastal Maine. Geological Society of America Bulletin, 108(8): 1022-1038.

Karrow, P. F., Greenhouse, J. P., and Ross, L. C. 1986. Subsurface Quaternary stratigraphy of the Kitchener-Waterloo area, Ontario. Geological Society of America Abstracts with Programs, 18: 312 .

Karrow, P. F. 1988. Catfish Creek Till: An important glacial deposit in southwestern Ontario. 41st Canadian Geotechnical Conference Preprints, Kitchener, Ontario, 186-192.

Karrow, P. F., and Paloschi, G. V. R. 1996. The Waterloo kame moraine revisited: new light on the origins of some Great Lake region interlobate moraines. Zeitschrift fuer Geomorphologie, 40(3): 305-315.

Krzyszkowski, D., and Karrow, P. F. 2001. Wisconsin inter-lobal stratigraphy in three quarries near Woodstock Ontario. Geographie Physique et Quaternaire, 55: 3-22. 
Larson, N. K., Piotrowski, J. A., and Christiansen, F. 2006. Microstructures and microshears as proxy for strain in subglacial diamicts: Implications for basal till formation. Geology, 34(10): 889 - 892.

Le Heron, D.P., and Etienne, J.L. 2005. A complex subglacial clastic dyke swarm, Solheimajokull, southern Iceland. Sedimentary Geology, 181: 25-37.

Lønne, I. 1995. Sedimentary facies and depositional architecture of ice-contact glaciomarine systems. Sedimentary Geology, 98: 13-43.

McDonald, B.C., and Shilts, W.W. 1975. Interpretation of faults in glaciofluvial sediments. In Glaciofluvial and glaciolacustrine sedimentation. Edited by A.V. Jopling and B.C. McDonald, SEPM Special Publication 23: 123-131.

Martin, P. J. and Frind, E. O. 1998. Modeling a complex multi-aquifer system: the Waterloo Moraine. Ground Water, 36(4): 679-690.

McCarroll, D. and Rijsdijk, K. F.. 2003. Deformation styles as a key for interpreting glacial depositional environments. Journal of Quaternary Science 18(6): 473-489.

Miall, A. D. 1977. A review of the braided-river depositional environment. Earth Science Reviews, 13(1): 1-62.

Mills, P. C. 1983. Genesis and diagnostic value of soft-sediment deformation structures-a review. Sedimentary Geology, 35: 83-104.

Ministry of Natural Resources, 2002. Provincial Digital Elevation Model- Tiled Data Set (DEM); Tiles $81,82,85,86$.

Nardin, T.R., Hein, F. J., Gorsline, D. S., Edwards, B. D. 1979. A review of mass movement processes, sediment and acoustic characteristics and contrasts in slope and base-ofslope systems versus canyon-fan-basin floor systems. In Geology of Continental 
Slopes. Edited by L.J. Doyle and O.H. Pilkey. Society of Economic Paleontologists and Mineralogists Special Publication, 27: 61-73.

Ontario Geological Survey (OGS) 2010. Surficial Geology of Southern Ontario. Ontario Geological Survey, Miscellaneous release-Data 128, revised.

Phillips, E. R., Evans, D. J. A., and Auton, C. A. 2002. Polyphase deformation at an oscillating ice margin following the Loch Lomond Readvance, central Scotland, UK. Sedimentary Geology, 149: 157-182.

Paloschi, G. V. R. 1993. Subsurface stratigraphy of the Waterloo moraine. MSc Thesis, Department of Earth Sciences, University of Waterloo, Waterloo, Ontario.

Piotrowski, J. A., Larsen, N. K., Menzies, J., and Wysota, W. 2006. Formation of subglacial till under transient bed conditions: deposition, deformation, and basal decoupling under a Weichselian ice sheet lobe, central Poland. Sedimentology, 53: 83-106.

Rajakaruna, N. 1994. The Waterloo Moraine Project Phase 1: Subsurface stratigraphy of western Kitchener-Waterloo, Ontario. MSc Thesis, Department of Earth Sciences, University of Waterloo, Waterloo, Ontario.

Rijsdijk, K.F., Warren, W.P., and van der Meer, J.J.M. 2010. The glacial sequence at Killiney, SE Ireland: terrestrial deglaciation and polyphase glacitectonic deformation. Quaternary Science Reviews, 29: 696-719.

Roberts, D. H. and Hart, J. K. 2005. The deforming bed characteristics of a stratified till assemblage in north East Anglia, UK: investigating controls on sediment rheology and strain signatures. Quaternary Science Reviews, 24(1-2): 123-140.

Russell, H. A. J., Sharpe, D. R. and Bajc, A. F. 2007. Sedimentary signatures of the Waterloo Moraine, Ontario, Canada. In Glacial Sedimentary Processes and Products. Edited by 
M. J. Hambrey, P. Christofferson, N. F. Glasser, and B. Hubbard, International Association of Sedimentologists Special Publication, 39: 85-108.

Statistics Canada, 2007a. Ontario Hydrology, Rivers 2006 Census (cartographic boundary file, ghy_035d06a_e.zip). Arc Info Edition. System requirements: Arc Info Interchange for Windows. These data are available at no additional charge to Canadian educational institutions participating in the Data Liberation Initiative.

Statistics Canada, 2007b. Ontario Hydrology, Lakes 2006 Census (cartographic boundary file, ghy_035c06a_e.zip). Arc Info Edition. System requirements: Arc Info Interchange for Windows. These data are available at no additional charge toCanadian educational institutions participating in the Data Liberation Initiative.

Statistics Canada, 2007c. Provinces and Territories, 2006 Census (cartographic boundary file, gpr_000b02_e.exe). Arc Info Edition. System requirements: Arc Info Interchange for Windows. These data are available at no additional charge to Canadian educational institutions participating in the Data Liberation Initiative.

Statistics Canada, 2007d. Ontario Dissemination Areas, 2006 Census (cartographic boundary file, gda_035b06a_e.zip). Arc Info Edition. System requirements: Arc Info Interchange for Windows. These data are available at no additional charge to Canadian educational institutions participating in the Data Liberation Initiative.

van der Meer, J. J. M., Menzies, J. and Rose, J. 2003. Subglacial till: the deforming bed. Quaternary Science Reviews, 22: 1659-1685.

Visher, G. S. and Cunningham R. D. 1981. Convolute laminations- a theoretical analysis: example of a Pennsylvanian sandstone. Sedimentary Geology, 28: 175-188. 
Weaver, L. and Arnaud, E. Polyphase glacigenic deformation in the Waterloo Moraine, Kitchener, Ontario, Canada. Sedimentary Geology (2010), doi:

10.1016/j.sedgeo.2010.07.008. 
Table 1. Summary of deformation observed in the Regional Municipality of Waterloo

\begin{tabular}{|c|c|c|}
\hline Deformation structures & \# of sites & Origin of deformation \\
\hline Chaotic bedding & 24 & $\begin{array}{l}\text { Gravitational instability } \\
\text { (sediment remobilization \& reversed } \\
\text { density gradients) }\end{array}$ \\
\hline Attenuated bedding & 10 & Simple shear stress (subglacial) \\
\hline Shear folds & 3 & Simple shear stress (subglacial) \\
\hline $\begin{array}{l}\text { Ball and pillow structures } \\
\text { and convolute bedding }\end{array}$ & 4 & $\begin{array}{l}\text { Gravitational instability } \\
\text { (reversed density gradients) }\end{array}$ \\
\hline Dikes & 3 & $\begin{array}{l}\text { Simple shear \& compressional stress } \\
\text { (subglacial) }\end{array}$ \\
\hline Normal faulting & 23 & $\begin{array}{l}\text { Gravitational instability } \\
\text { (melting of buried or supporting ice) }\end{array}$ \\
\hline $\begin{array}{l}\text { High-angle Reverse } \\
\text { Faults }\end{array}$ & 9 & $\begin{array}{l}\text { Gravitational instability } \\
\text { (melting of buried or supporting ice) / } \\
\text { Simple shear \& compressional stress } \\
\text { (proglacial) }\end{array}$ \\
\hline $\begin{array}{l}\text { Low-angle Reverse } \\
\text { (Thrust) Faults }\end{array}$ & 2 & $\begin{array}{l}\text { Simple shear \& compressional stress } \\
\text { (proglacial) }\end{array}$ \\
\hline Undifferentiated Faults & 6 & Unknown \\
\hline Undeformed & 227 & -- \\
\hline Total & 311 & \\
\hline
\end{tabular}


Table 2. Scale of deformation throughout the region

\begin{tabular}{ll}
\hline Scale of & Number of sites \\
Deformation & \\
\hline$<0.25 \mathrm{~m}$ & 27 \\
$0.25-0.50 \mathrm{~m}$ & 1 \\
$0.50-1 \mathrm{~m}$ & 9 \\
$1-2 \mathrm{~m}$ & 11 \\
$>2 \mathrm{~m}$ & 35 \\
\hline
\end{tabular}

${ }^{*}$ One site was unclassified. 


\section{Figure Captions}

Fig. 1. Map of southwestern Ontario showing the Waterloo Moraine in relation to the late Wisconsinan ice lobes of the Laurentide Ice Sheet (modified from Barnett (1992); moraine outline taken from Bajc and Shirota (2007)).

Fig 2. Map of the Regional Municipality of Waterloo showing the extent of the Waterloo Moraine, regional topography and study sites with deformed and undeformed sediments. Note the SE-NW trending regional ridge (black arrows). Moraine outline taken from Bajc and Shirota (2007). Map produced using base map data from Statistics Canada (2007a-d) and DEM data from Ministry of Natural Resources (2002).

Fig. 3. A) Conceptual cross-section of the moraine modified from Bajc (2004). MTMornington Till; TT-Tavistock Till; ST-Stirton Till; MHT-Maryhill Till; CCT-Catfish Creek Till; CD-Canning Drift; PST-Port Stanley Till.

Fig. 4. A) Chaotic bedding in coarse-grained gravel sediment over an inclined erosional surface cut into sand, Preston Sand and Gravel Company Ltd. B\&B Pit, Panel LW-09 (white arrow indicates flow direction, black arrow points to flow nose). B) Contorted and convoluted sand, Kieswetter Holdings Ltd., location X21. Note black section of metre stick is $10 \mathrm{~cm}$.

Fig 5. A) Attenuated bedding of clay-silty sand, Kieswetter Holdings Ltd., Panel LW-122005; Metre stick at far right for scale; B) Large-scale loading structure including large load cast (dashed line), flame structure (left arrow) and pseudonodule (right arrow), Preston Sand 
and Gravel Company Ltd. B\&B Pit, Panel LW-06. Metre stick shows $10 \mathrm{~cm}$ increments; C) Shear fold (arrow) of sand at the base of a diamict unit, Preston Sand and Gravel Company Ltd., Woolner Flats pit, Panel WF-2; D) Dikes (arrows) infilled with clay, silt and sand cross cutting massive sand, Preston Sand and Gravel Company Ltd., Woolner Flats pit, Panel WF-1.

Fig. 6. Panel diagram of extensive normal faulting in interbedded sand and gravel, Kieswetter Holdings Ltd., Panels 2-6 (2005). See inset map for relative orientation and distribution of panels.

Fig 7. A) Photograph of normal faulting in interbedded sand and gravel, Kieswetter Holdings Ltd., Panel 6 (2005). Offset is $64 \mathrm{~cm}$; B) Photograph of reserve faulting (white arrows) in fine sand, Panel 10 (2007), Kieswetter Holdings Ltd. Note black increments on metre stick are 10 $\mathrm{cm}$.

Fig. 8. Panel diagram of a reverse fault, Preston Sand and Gravel Company Ltd. Cedar Creek Pit, Panel 1.

Fig. 9. Panel diagrams showing complex and varied deformation structures in relatively close proximity. Preston Sand and Gravel Company Ltd., B \& B Pit. See inset map for relative orientation and distribution of the four sites. 
Fig. 10. Distribution of dominant deformation in the Regional Municipality of Waterloo: shear and compressional deformation; deformation related to gravitational instability and sites with undeformed sediments.

Fig. 11. Texture of dominant deformation structures in the Regional Municipality of Waterloo. Inset A) and B) show distribution of dominant deformation in the cluster or deformed complexes. Note that 58 sites $(69 \%)$ had deformation structures consisting of sand and gravel, whereas 26 sites (31\%) had deformation structures consisting of silt, clay or diamict.

Fig. 12. Map showing relationship between sites, where deformation involves, or is associated with, diamict, and the surficial distribution of local tills as mapped by the Ontario Geological Survey (2010). Inset A) and B) shows this relationship in the cluster or deformed complexes. Map produced using surficial geology data from Ontario Geological Survey (2010) under License with the Ontario Ministry of Northern Development and Mines (C Queen's Printer for Ontario, 2010.

Fig. 13. Scale of dominant deformation observed in the Regional Municipality of Waterloo. Inset A) and B) show distribution of the scale of deformation in the clusters or deformed complexes. Note most deformation is $<25 \mathrm{~cm}$ ( 27 sites or $32 \%$ ) or $>2 \mathrm{~m}$ thick (35 sites or $42 \%)$. 
Fig. 14. Conceptual diagram showing distribution of depositional settings based on deformation styles and lithofacies within the region, as ice retreated southeastwardly from the region during the early Port Bruce Stade (see text for discussion). Glaciolacustrine conditions predominate, though lake stage likely varied in response to fluctuating ice lobe margins during the deposition of the units shown. 


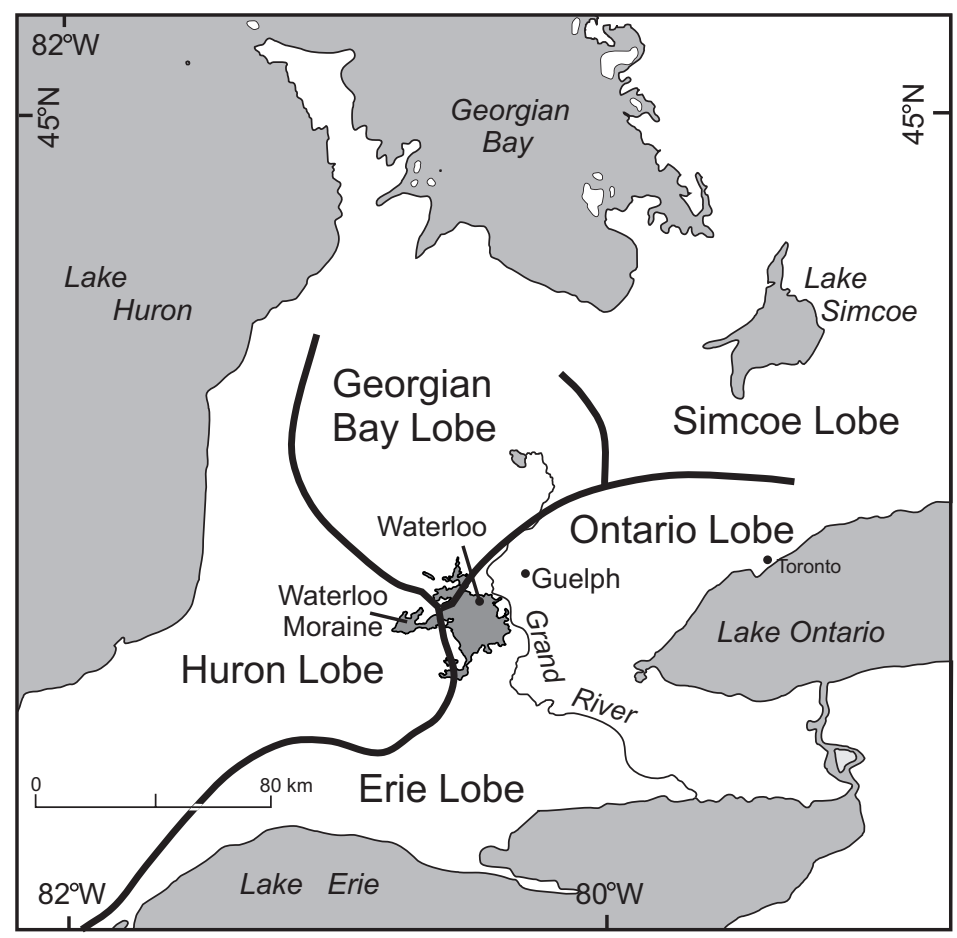

Fig. 1 


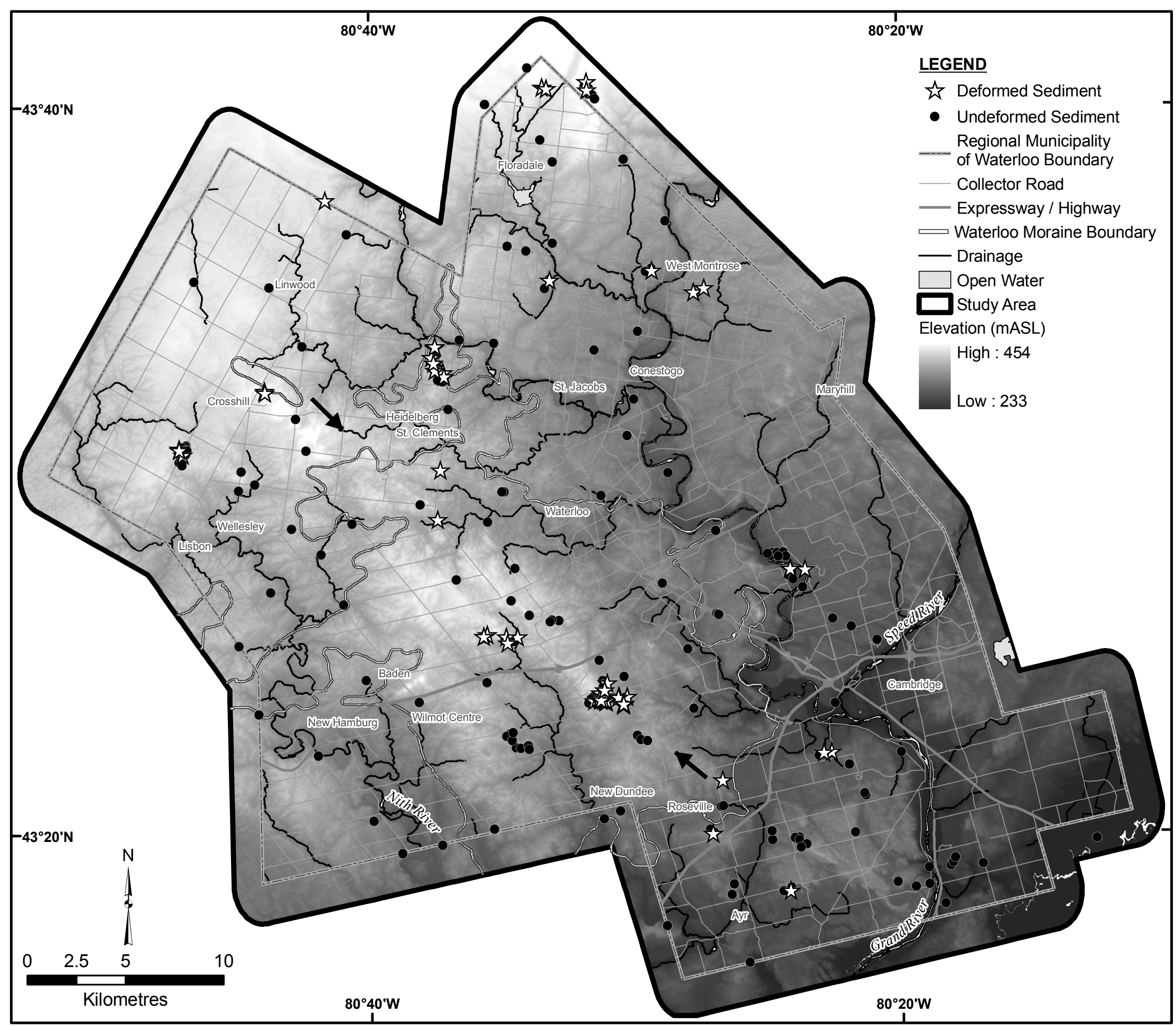

Fig. 2 


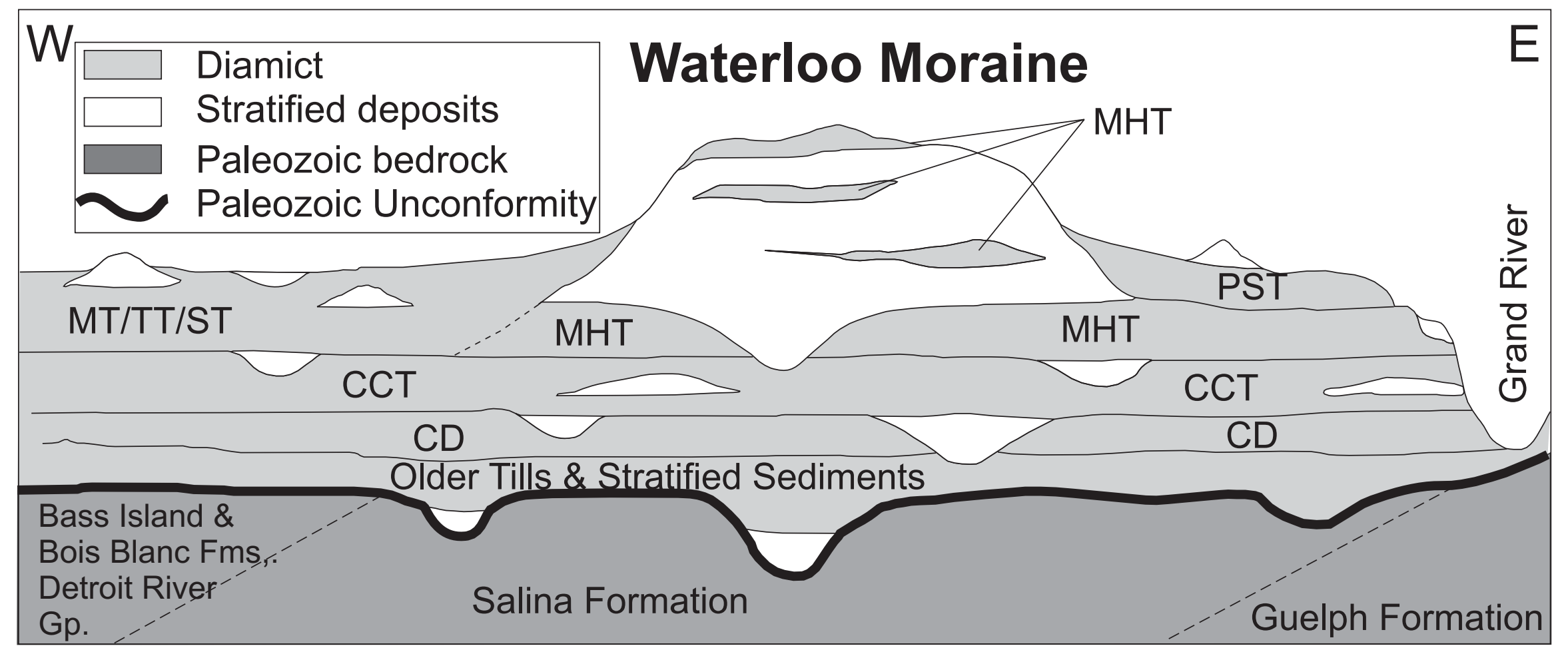

Fig. 3 

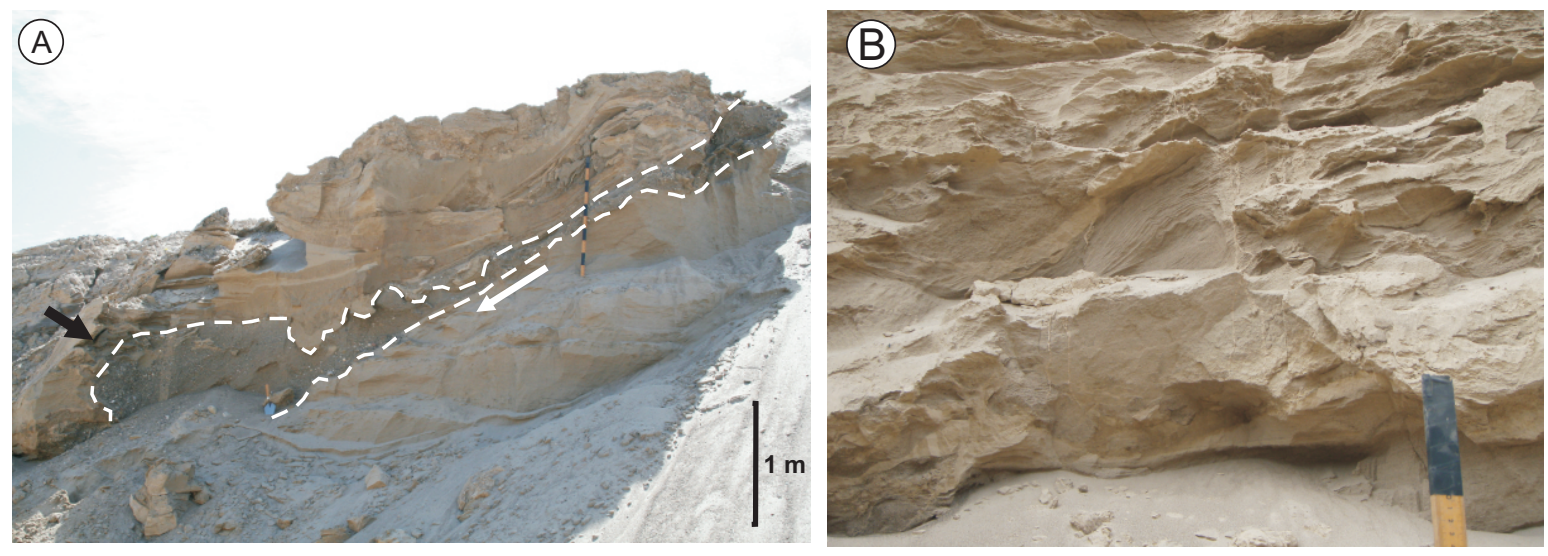

Fig. 4 

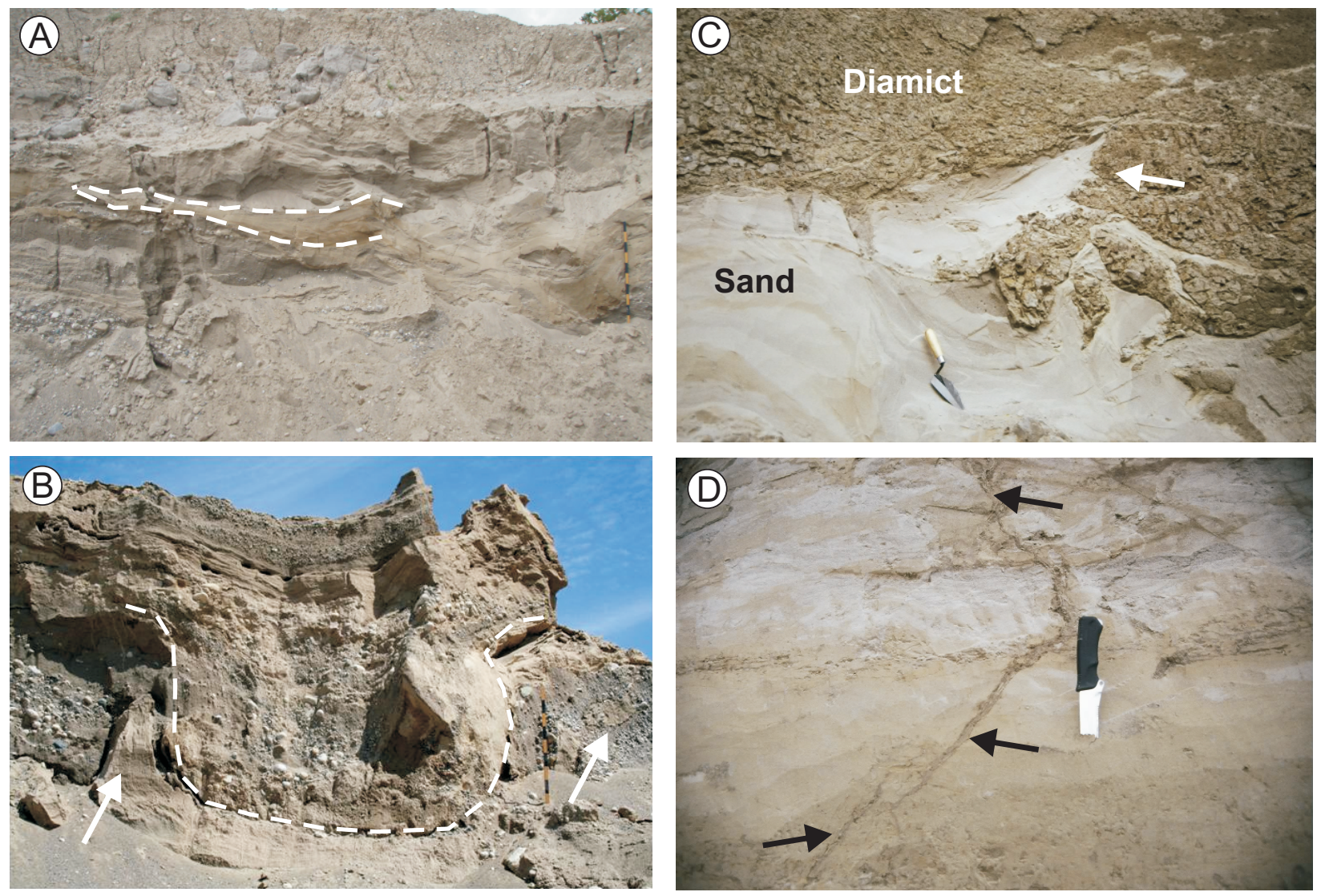

Fig. 5 


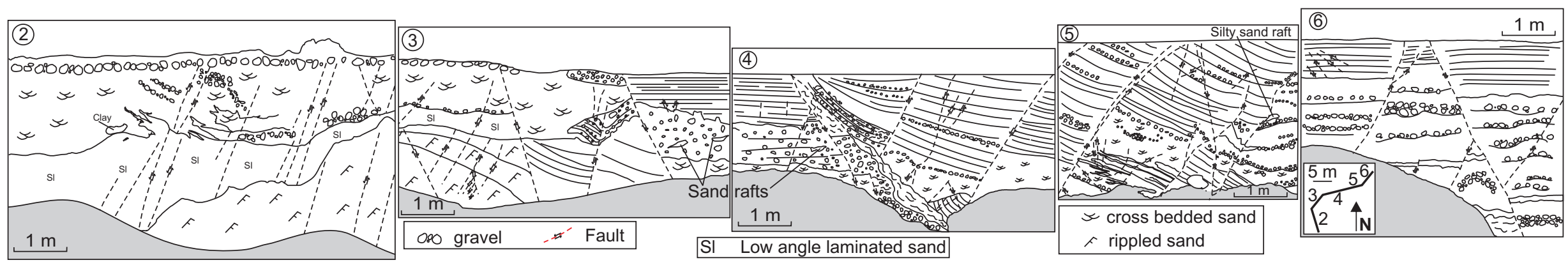

Fig. 6 

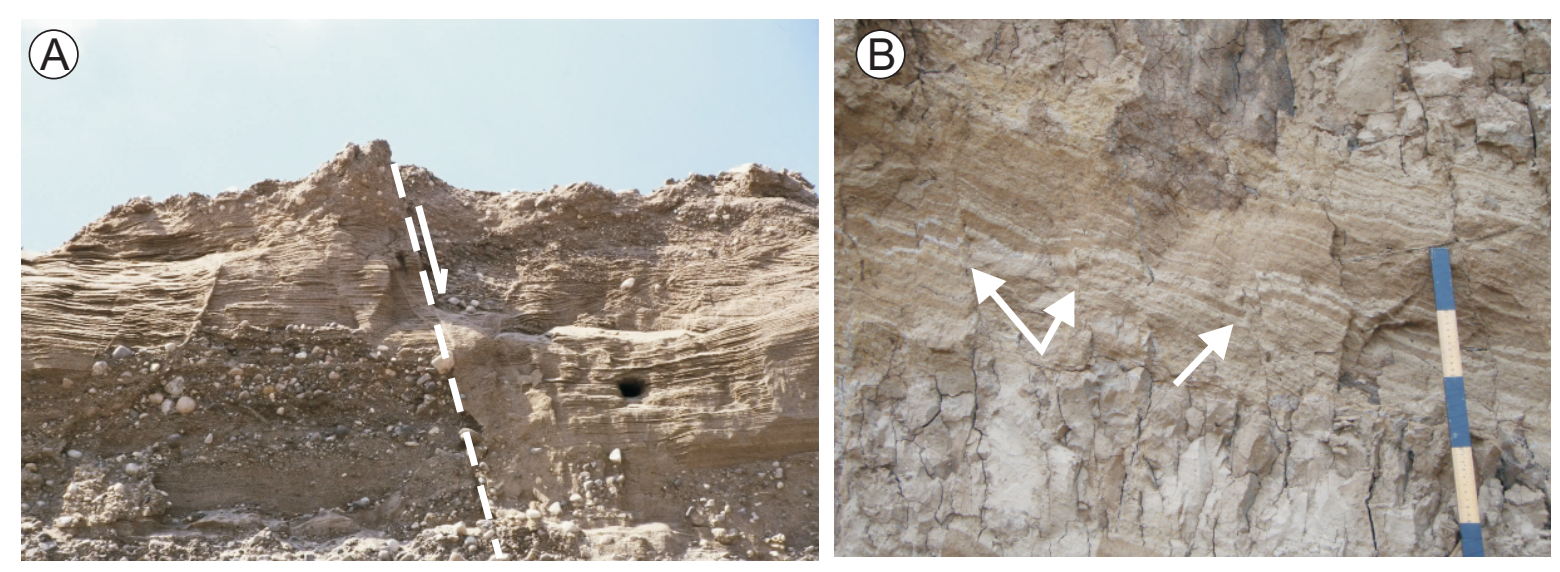

Fig. 7 


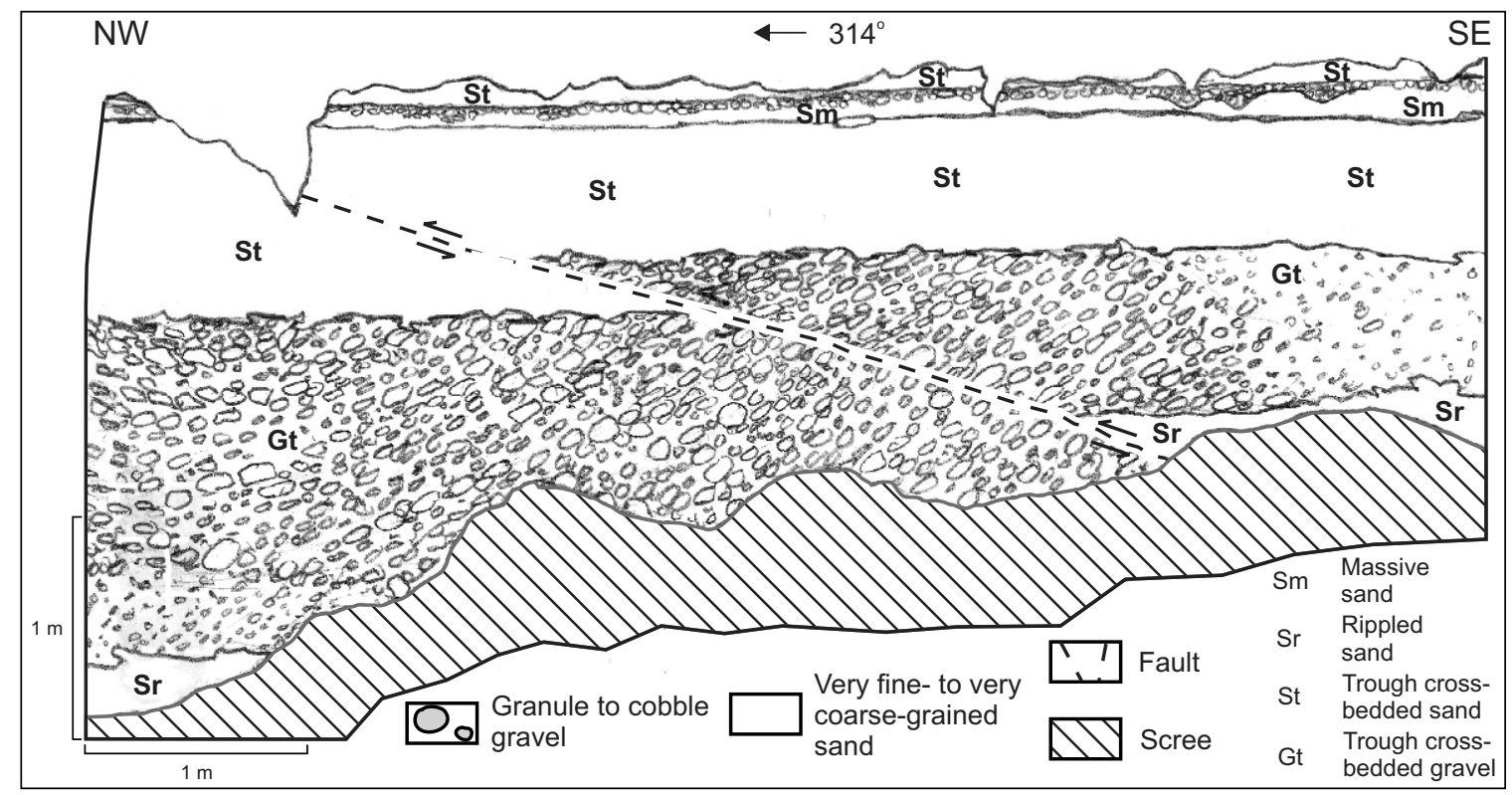

Fig. 8 


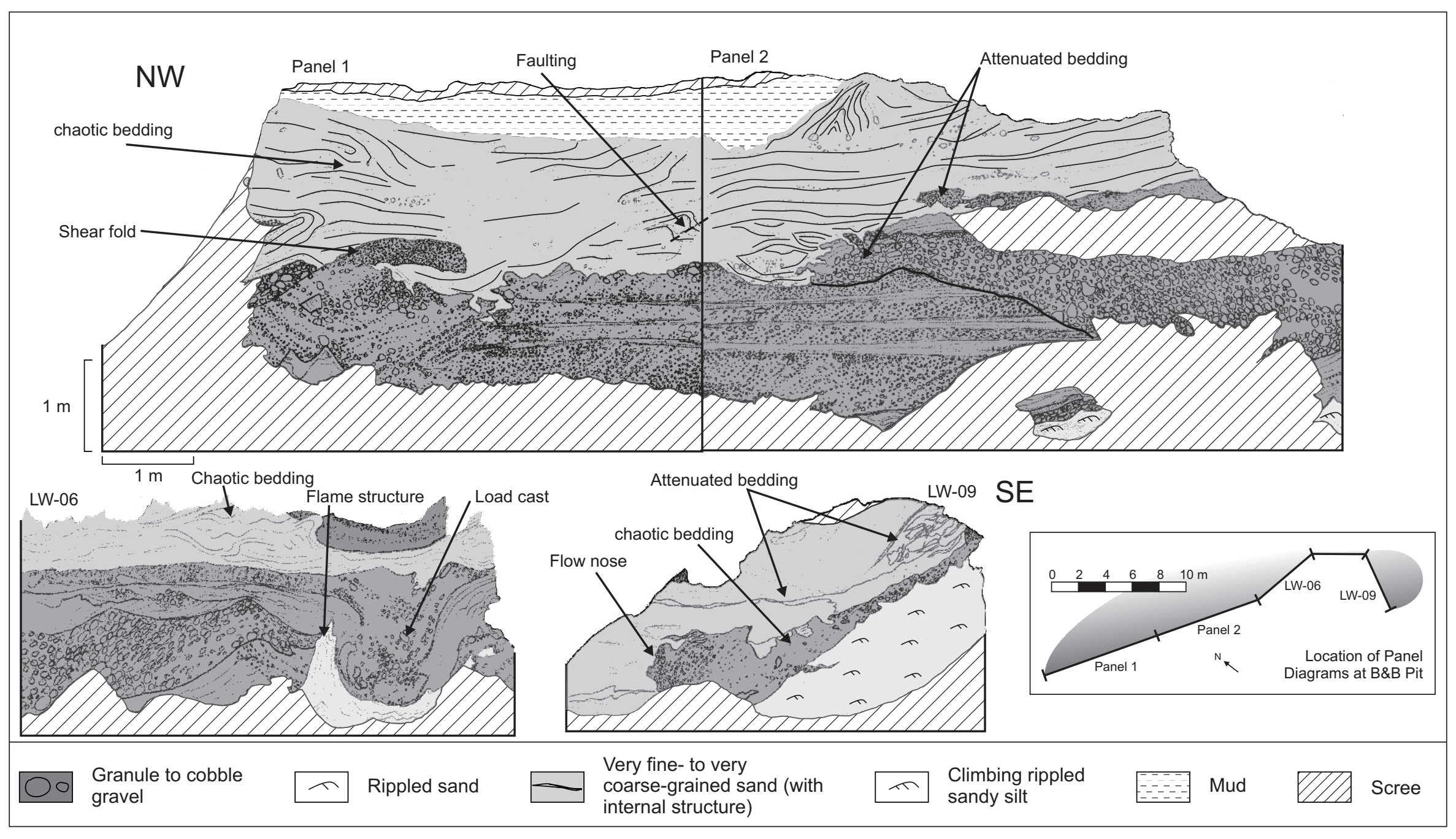

Fig. 9 


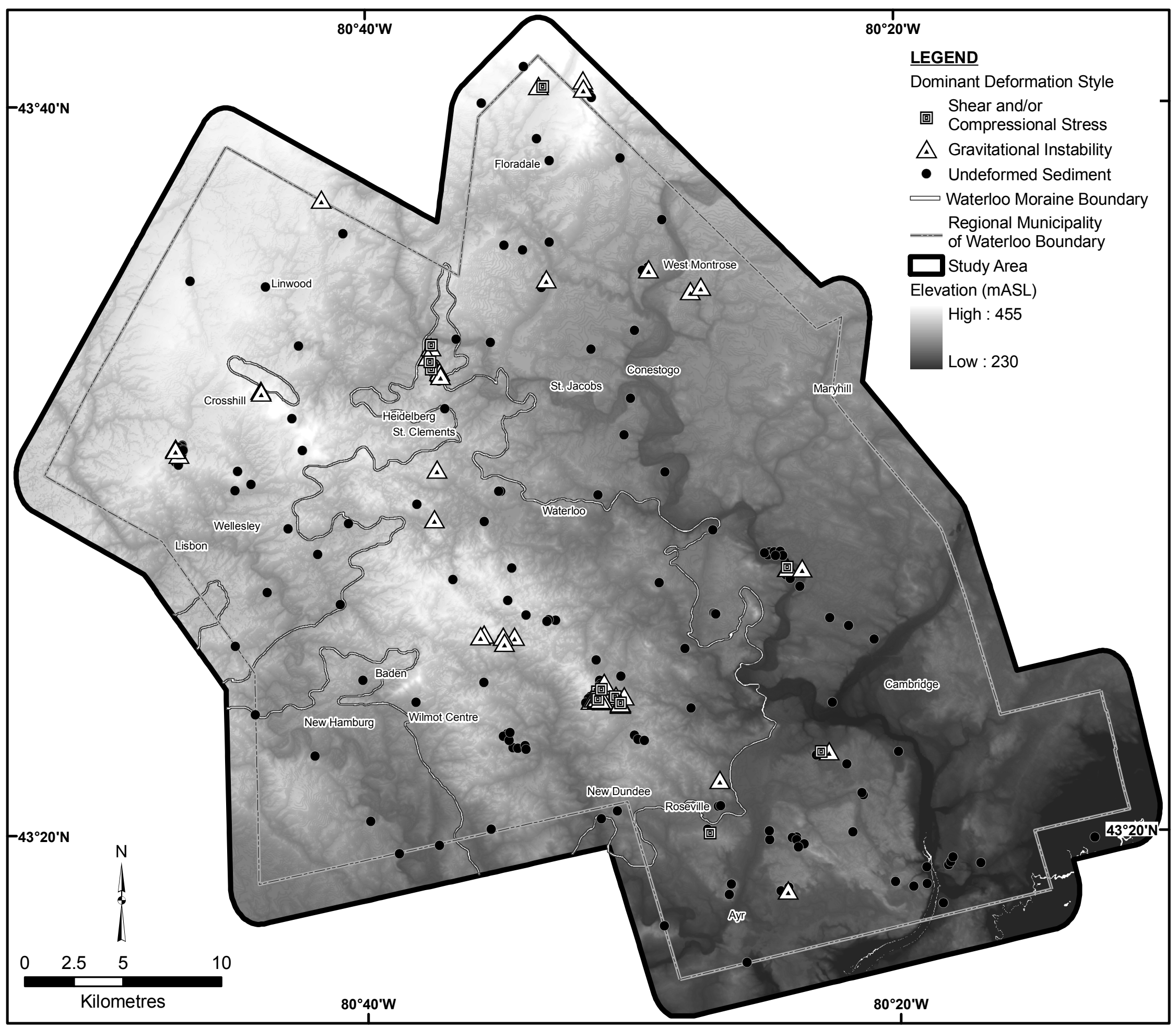

Fig. 10 


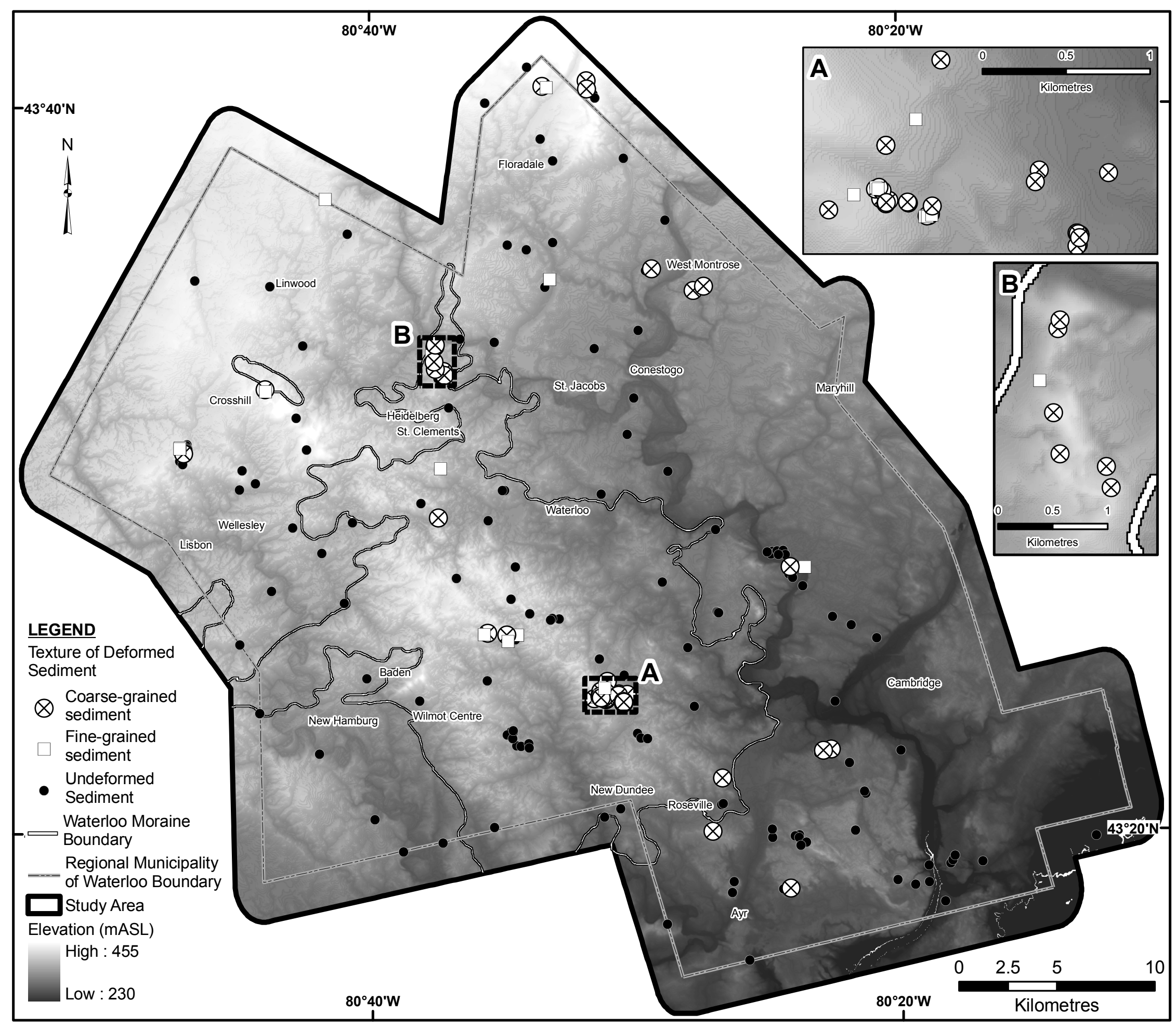




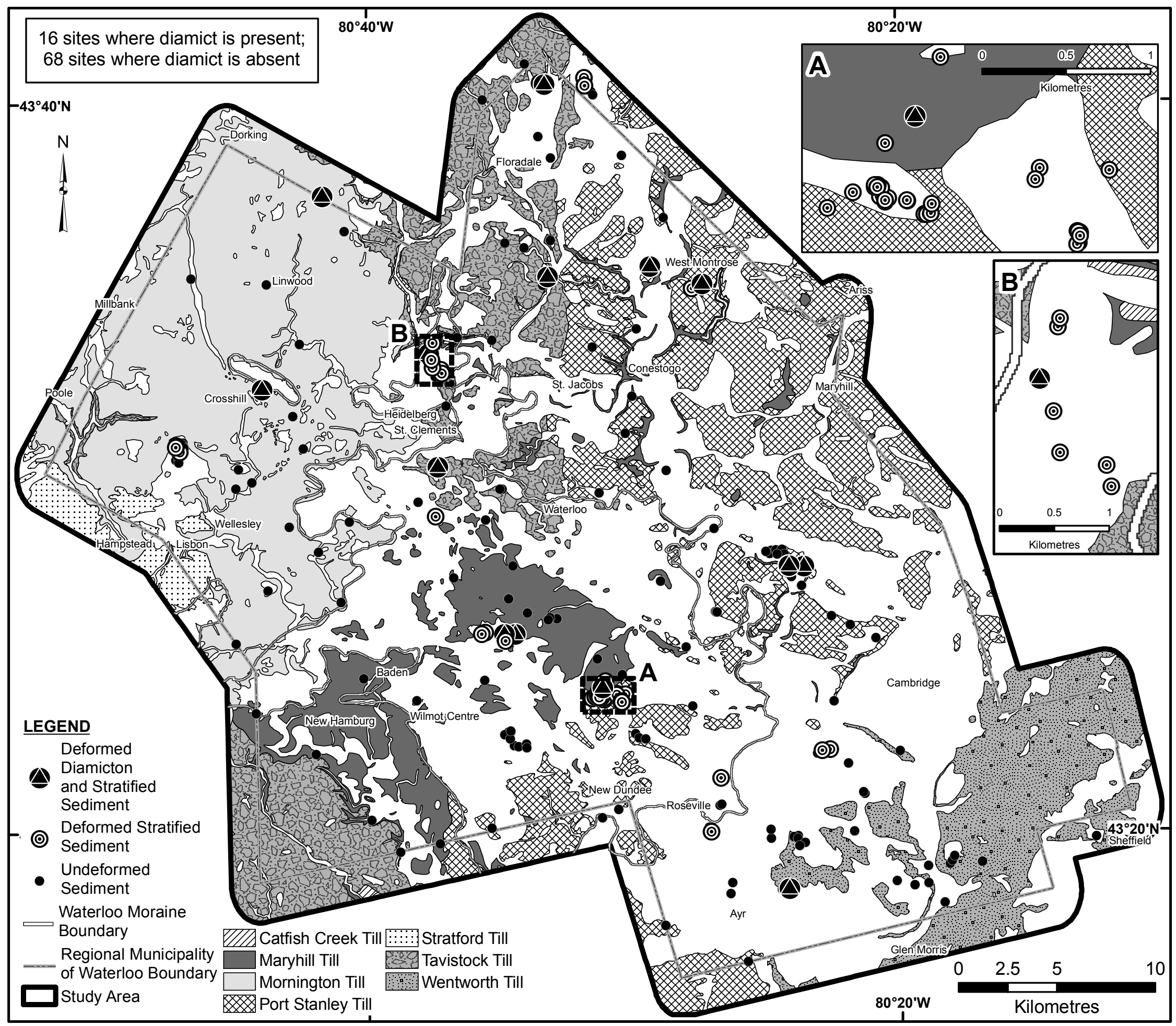

Fig. 12 


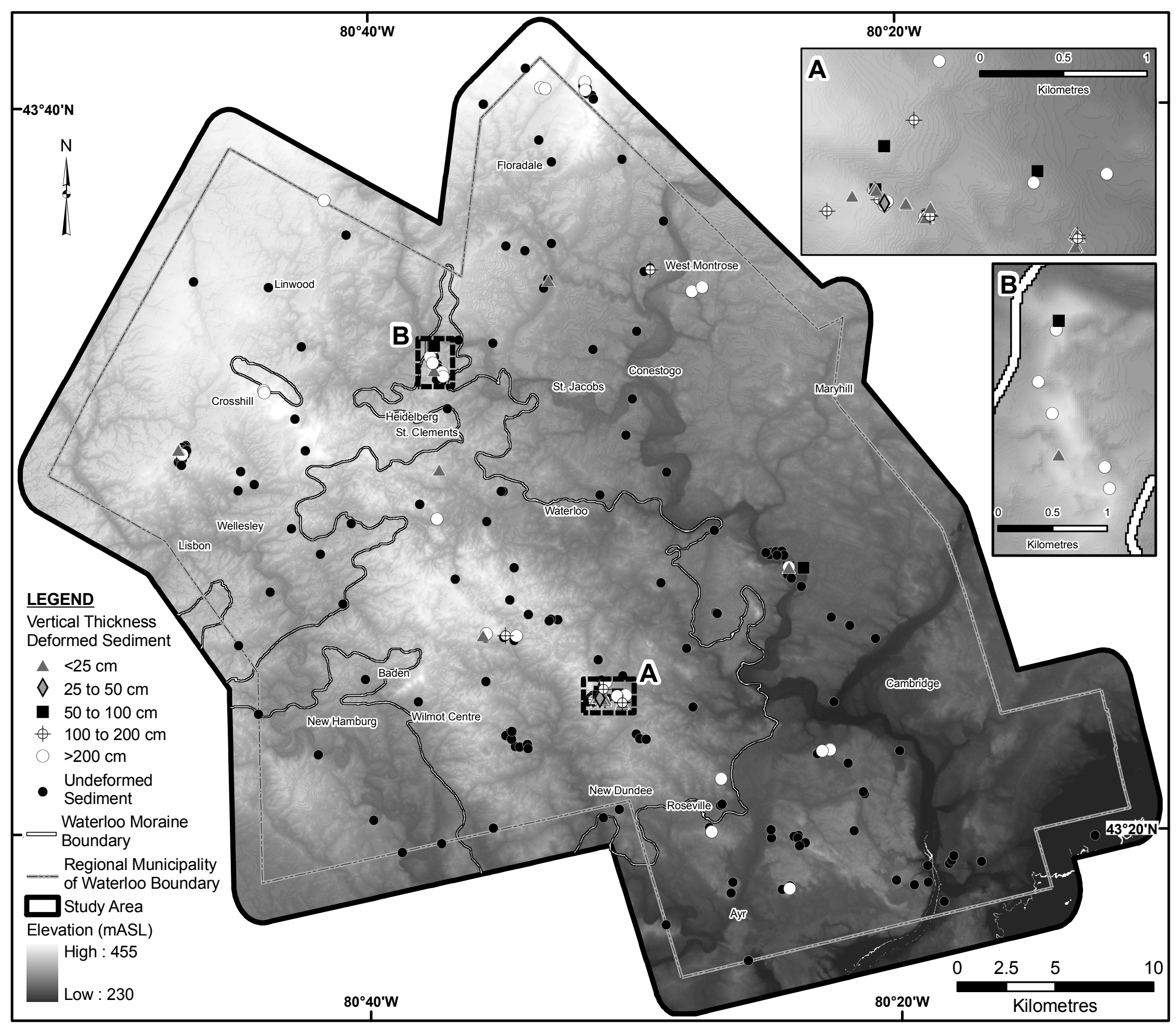




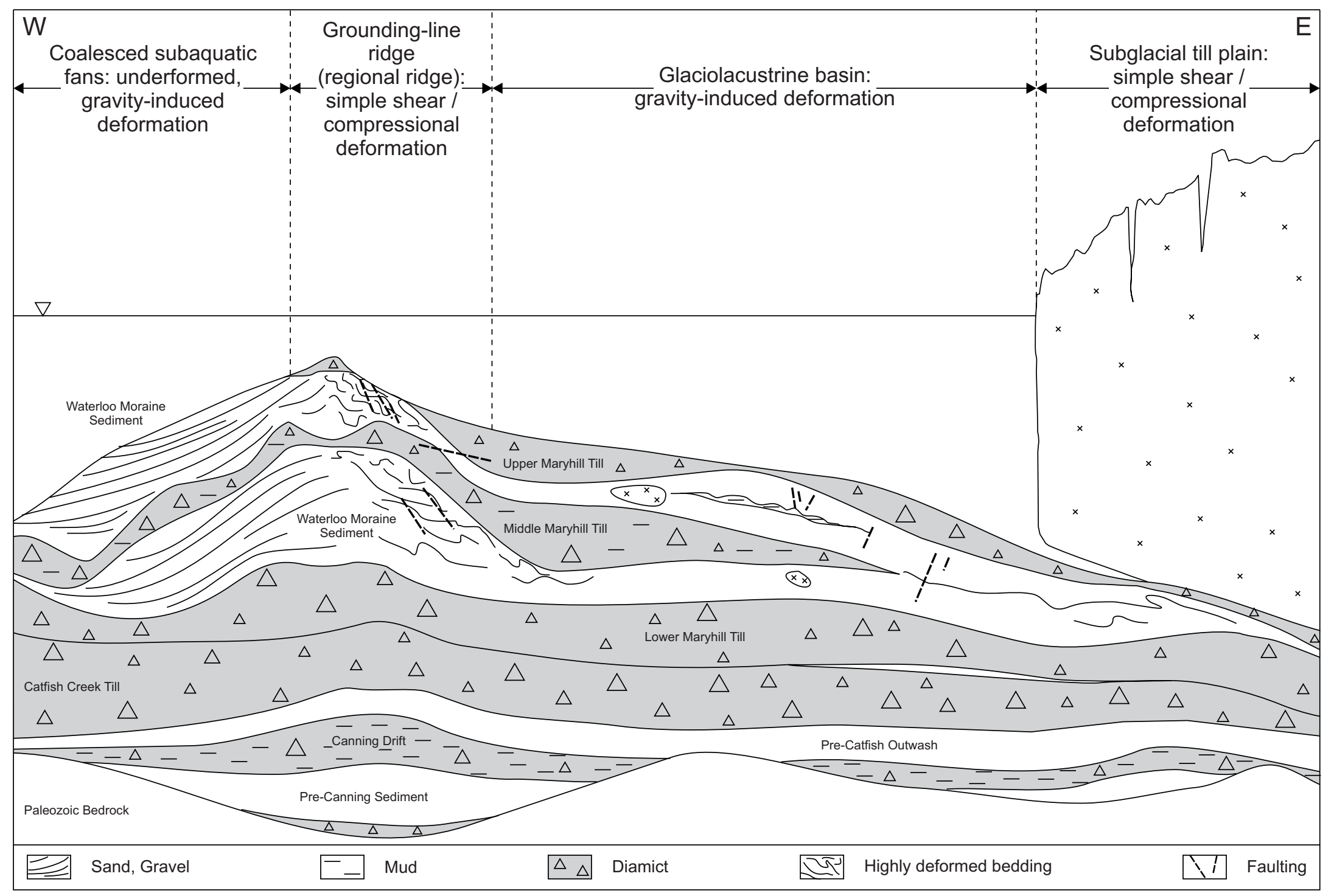

Fig. 14 